ARGONNE NATIONAL LABORATORY

9700 South Cass Avenue, Argonne, Illinois 60439

ANL/EES-TM-311

\title{
ENERGY RESEARCH AND DEVELOPMENT \\ PROFILE OF AUSTRALIA
}

\author{
ANL/EES-TH--311 \\ DE86 015002
}

\begin{abstract}
by
Lisa Kenkeremath

Energy and Environmental Systems Division
\end{abstract}

January 1986

work sponsored by

U.S. DEPARTMENT OF ENERGY Assistant Secretary for Fossil Energy

Deputy Assistant Secretary for Oil, Gas, Shale, and Coal Liquids 


\section{CONTENTS}

FOREWORD $\ldots \ldots \ldots \ldots \ldots \ldots \ldots \ldots \ldots \ldots \ldots \ldots \ldots \ldots \ldots \ldots \ldots \ldots \ldots \ldots \ldots \ldots \ldots \ldots$

SUMMARY $\ldots \ldots \ldots \ldots \ldots \ldots \ldots \ldots \ldots \ldots \ldots \ldots \ldots \ldots \ldots \ldots \ldots \ldots \ldots \ldots \ldots \ldots \ldots \ldots \ldots \ldots \ldots \ldots \ldots$

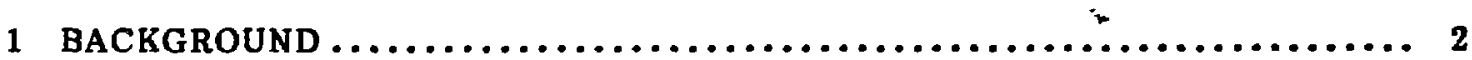

1.1 The Australian Economy $\ldots \ldots \ldots \ldots \ldots \ldots \ldots \ldots \ldots \ldots \ldots \ldots \ldots \ldots \ldots \ldots \ldots \ldots \ldots 2$

1.2 The Energy Situation in Australia ............................. 3

1.3 Australia's Energy Policy ................................ 3

2 ENTITIES RESPONSIBLE FOR ENERGY R\&D $\ldots \ldots \ldots \ldots \ldots \ldots \ldots \ldots \ldots \ldots \ldots \ldots \ldots \ldots$

2.1 Historical Role of Australian Government ...................... 5

2.2 Current Roles and Responsibilities of Government Agencies ............ 5

2.3 State Government Sponsorship of R\&D ......................... 8

2.4 Nongovernment Cooperation in $R \& D \ldots \ldots \ldots \ldots \ldots \ldots \ldots \ldots \ldots \ldots \ldots \ldots \ldots \ldots \ldots$

3 AUSTRALIA'S ENERGY R\&D PROGRAM $\ldots \ldots \ldots \ldots \ldots \ldots \ldots \ldots \ldots \ldots \ldots \ldots \ldots$

3.1 Background .......................................... 10

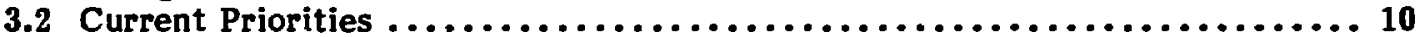

3.3 Criteria for Funding $R \& D$ Projects $\ldots \ldots \ldots \ldots \ldots \ldots \ldots \ldots \ldots \ldots \ldots \ldots \ldots \ldots \ldots \ldots$

3.4 Current Funding Levels $\ldots \ldots \ldots \ldots \ldots \ldots \ldots \ldots \ldots \ldots \ldots \ldots \ldots \ldots \ldots \ldots \ldots \ldots \ldots$

4 FOSSIL ENERGY RESERVES $\ldots \ldots \ldots \ldots \ldots \ldots \ldots \ldots \ldots \ldots \ldots \ldots \ldots \ldots \ldots \ldots \ldots \ldots \ldots$

5 OIL, GAS, SHALE, AND COAL LIQUIDS R\&D . . . . . . . . . . . . . . . . . . . . 19

5.1 Rationale for Oil, Gas, Shale, and Coal Liquids Research . . . . . . . . . . . . . . 19

5.2 Government Policies in Support of Oil, Gas, Shale, and Coal

Liquids Development in Australia . . . . . . . . . . . . . . . . . . . . . . . . 19

5.3 Research Programs and Funding .............................. 21

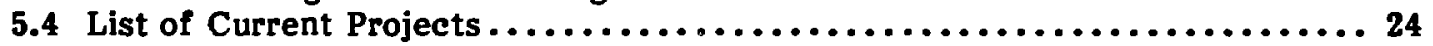

6 INTERNATIONAL COLLABORATIONS IN OIL, GAS, SHALE, AND

COAL LIQUIDS R\&D .................................... 26

6.1 Rationale and Orientation $\ldots \ldots \ldots \ldots \ldots \ldots \ldots \ldots \ldots \ldots \ldots \ldots \ldots \ldots \ldots \ldots \ldots$

6.2 Agencies Fostering Cooperative R\&D $\ldots \ldots \ldots \ldots \ldots \ldots \ldots \ldots \ldots \ldots \ldots \ldots \ldots \ldots \ldots \ldots$

6.3 Bilateral Agreements ................................... 27

6.4 Multilateral Agreements $\ldots \ldots \ldots \ldots \ldots \ldots \ldots \ldots \ldots \ldots \ldots \ldots \ldots \ldots \ldots \ldots \ldots \ldots \ldots \ldots \ldots \ldots . . .29$

7 INDUSTRIAL PARTICIPATION IN COAL LIQUIDS, OIL SHALE, AND

NATURAL GAS R\&D ................................... 30

7.1 Coal Liquids $\ldots \ldots \ldots \ldots \ldots \ldots \ldots \ldots \ldots \ldots \ldots \ldots \ldots \ldots \ldots \ldots \ldots \ldots \ldots \ldots \ldots \ldots \ldots$

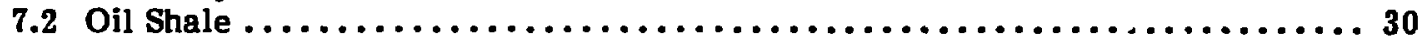

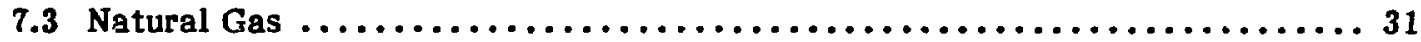

SOURCES CONSULTED $\ldots \ldots \ldots \ldots \ldots \ldots \ldots \ldots \ldots \ldots \ldots \ldots \ldots \ldots \ldots \ldots \ldots \ldots \ldots \ldots \ldots \ldots \ldots$ 


\section{TABLES}

1 Australian In-Situ Shale Oil Reserves .......................... 16

2 Black Coal Resources of Australia $\ldots \ldots \ldots \ldots \ldots \ldots \ldots \ldots \ldots \ldots \ldots \ldots \ldots \ldots \ldots \ldots \ldots$

3 Victorian Brown Coal Reserves $\ldots \ldots \ldots \ldots \ldots \ldots \ldots \ldots \ldots \ldots \ldots \ldots \ldots \ldots \ldots$

\section{FIGURES}

1 Reporting Relationships for Energy Activities Carried Out Under the Minister for Seience and Technology $\ldots \ldots \ldots \ldots \ldots \ldots \ldots \ldots \ldots \ldots \ldots \ldots \ldots \ldots \ldots \ldots \ldots$

2 Reporting Relationships for Energy Activities Carried Out Under the Minister for Resources and Energy 


\section{FOREWORD}

Within the U.S. Department of Energy, the Deputy Assistant Secretary for Oil, Gas, Shale, and Coal Liquids (OGSCL) seeks to advance international collaboration in research and development programs. As part of this effort, Argonne National Laboratory reviews the energy situation and associated research and development programs and plans of selected countries. The depth of the review depends upon the informational needs of OGSCL. This report presents a review for Australia. 


\section{ENERGY RESEARCH AND DEVELOPMENT \\ PROFILE OF AUSTRALIA}

by

Lisa Kenkeremath

\section{SUMMARY}

Australia is a large, sparsely populated country with an economy based traditionally on raw materials exports. Though still a major international trader in minerals and agricultural products, Australia has suffered a decline in productivity, employment, exports, and economic growth since the 1950s.

The country possesses vast reserves of black and brown coal, shale, and natural gas, but has extremely limited oil reserves. Since Australia is expected to depend more and more on imported oil to meet its energy demands in the 1990s, the Australian government is committed to reducing this dependency by replacing oil with fuels from the indigenous energy resources which are in abundant supply. Achieving energy independence will thus entail, in addition to such measures as energy conservation, petroleum exploration, and petroleum stockpiling, the development of cost-effective technologies for alternative energy sources, particularly liquid fuels. Besides helping to meet the country's own energy needs, development of a synthetic fuels industry based on coal, gas, and shale resources could be an important source of export income.

Most energy research and development (R\&D) snd policymaking activities are carried out under the National Energy Research, Development, and Demonstration (NERDD) program. The NERDD program priorities include, among others, production of liguid hydrocarbon fuels from natural gas or coal-derived synthesis gas and oil and gas exploration, assessment, and recovery technology (high priority); production of liquid fuels from coal and oil shale by hydrogenation or pyrolysis, coal gasification, and achievement of cost reductions in coal and oil shale exploration and assessment techniques (medium priority); and in-situ coal gasification (low priority).

Bilateral agreements for energy $R \& D$ with other countries are carried out under the Australian Department of National Development and Energy. Australia currently has agreements related to oil, gas, shale, and coal liquids R\&D with the U.K., the U.S., Japan, and West Germany. These projects are in the areas of coal extraction, processing, and conversion and include a brown coal liquefaction pilot plant being built by the Japanese government in Victoria state.

The Australian Science and Technology Council has recently set forth eriteria for future cooperative agreements. These criteria relate to the technical expertise and facilities of the partner country, endorsement by the Australian technical community, availability of scientific and financial resources in Australia and the partner country, evidence of clear benefits to Australia, and other concerns. 


\section{BACKGROUND}

\subsection{THE AUSTRALIAN ECONOMY}

In the late nineteenth century Australia began to develop largely along the lines of the colonial model of technology transfer, exchanging gold, wheat, and wool for technology and technological expertise. The greatest investors in Australia were not Australian private businesses, but various colonial governments. Foreign corporations were encouraged to establish themselves in Australia, and they of ten took over locallyowned companies. Foreign interests in the country now include motor manufacturing, oil, computers, electronics, chemicals, plastics, and pharmaceuticals.

Australia today is a major international trader in raw materials, chiefly coal, wool, wheat, metals, and iron ore. The country is the largest bauxite and a'umina producer in the world and the largest exporter of iron ore. To a certain extent Australia has been adversely affected by the shift in Western economies from a resources and manufacturing base to a skills base. Australia has experienced a long decline in productivity, employment, exports and economic growth over the last 30 years. Between 1962 and 1980 only 4 out of 24 countries in the Organization for Economic Cooperation and Development (OECD) had a per-capita growth rate in gross domestic product (GDP) lower than that of Australia, and Australia's ranking in terms of per-capita GDP fell from ninth to twelf th.

In spite of its supremacy in the raw materials trade, Australia now has a postindustrial economy; since 1965 virtually all new jobs created have been in "services." A recent four-sector labor force analysis showed that more Australians now work in "information" than in farming, mining, and manufacturing combined. The decline of the traditional industries is most apparent in the manufacturing sector, where the percentage share of GDP slipped from $28.8 \%$ in 1963 to $21 \%$ in 1979 and is still falling. This is also reflected in the very low ratio of exports to imports relative to other OECD countries and the particularly low level of exports of technology-intensive products.

Private industry research and development, when measured as a percentage of GDP, is one of the lowest of all OECD countries. Only $0.2 \%$ of GDP was spent on research by industry in 1978-79, compared with $1.9 \%$ in countries of relatively comparable population, such as Switzerland and Sweden.

The Labor government elected in March 1983 came to office with a detailed recovery and reconstruction policy aimed at reversing these trends and promoting Australia's technological autonomy. Despite a tight budget for 1983-84 the new government increased spending on industrial research and development by $36 \%$. It also more than tripled funding for technology programs and introduced a new tax incentive scheme to boost the venture-capital market in Australia.

Current science and technology policy identifies sixteen "sunrise" incustries meriting government support because of the country's comparative advantage in technology development or strategic location. These industries include biotechnology, microelectronics, solar technologies, medical technologies, and others. These "sunrise" 
industries, though not expected to be major employers in themselves, are expected to be major "wealth generators" that will have second- and third-order effects on employment.

Under the policies of the new Labor government Australia would begin a shift from a resource-based economy dependent on income generated by its mineral and agricultural exports to a skill-based economy founded on new high-technology enterprises. The Minister of Science and Technology, Barry Jones, is leading a strong push in the new-technology direction, arguing that Australia must set up new industries to prevent its economic base from contracting. More conservative eiements of industry, the financial community, and government feel that the country should continue to concentrate on its traditional industries, such as mining and agriculture, and to prop up its declining manufacturing sector with more protective tarifs. These groups argue against extra support for the new industries, preferring to let market forces determine their success or failure.

\subsection{THE ENERGY SITUATION IN AUSTRALIA}

Australia has vast deposits of black coal, with identified recoverable amounts of $300 \cdot 10^{9} /$ metric tons $(t)$, and extensive natural gas reserves both onshore and offshore. In comparison to those resources, the country's oil reserves are poor; its known reserves of crude oil and condensate stand at around $1900 \cdot 10^{6}$ barrels (bbl). At the current rate of consumption of just under $0.6 \cdot 10^{6} \mathrm{bbl} / \mathrm{d}$, the estimated reserves would last for about nine years. Currently, Australia produces about $80 \%$ of its crude oil needs; without additional oil discoveries, this rate is expected to drop to $67 \%$ in 1990 and to less than $44 \%$ by 1994 . The country's Bureau of Mineral Resources estimates that prospects are good for finding another $650 \cdot 10^{6}$ bbl before 1994; such a discovery would raise Australia's oil self-sufficiency to about $72 \%$.

\subsection{AUSTRALIA'S ENERGY POLICY}

Australia's energy policy is formulated in the context of Australia's federal system, within which six states and the Northern Territory have considerable autonomy over the policies applying to their own resources, consumption, and degree of involvement in energy activities.

Energy policy responsibility is shared between the Australian Commonwealth government and state and Northern Territory governments. The Commonwealth owns offshore resources beyond a limit of three miles, administering them together with its states adjacent to those resources, and sets import and export policy; the states own onshore resources (except that the federal government controls uranium in the Northern Territory) and operates internal utility services such as electricity and, in most cases, natural gas.

The coordination of federal and state policies is pursued at a number of levels. The Australian Minerals and Energy Council (AMEC) is the formal body through which Commonwealth, Northern Territory, and state governments discuss energy issues and coordinate actions. 
The Australian government's energy policy objectives are summarized as follows:

1. To attempt to ensure that an adequate supply of energy is available at all times.

2. In relation to liquid fuels,

a. To prepare Australia for major oil-supply interruptions through stockpiling and emergency allocation schemes and other short-lead-time measures;

b. To achieve the optimum economic level of liquid fuels selfsufficiency by:

- Encouraging conservation and more efficient use of liquid fuels;

- Replacing oil use by relatively abundant energy sources such as coal and natural gas;

- Encouraging petroleum exploration and development; and

- Developing technologies for alternative energy sources, particularly liquid fuels and including renewable resources.

3. To facilitate the efficient use of energy in Australia and the efficient development of its energy resources in response to the needs of domestic and overseas energy markets.

4. To ensure that the benefits of energy resource development are shared equitably throughout the Australian community.

The principal policy instrument aimed at achieving the above objectives is the import parity pricing of indigenous crude oil. Measures such as taxation, foreign investment, technology transfer, and energy $R \& D$ are seen as important supplementary policy tools. The recent government decision to increase the level of energy spending for research, development, and demonstration projects thus takes into account the comparative effectiveness of the non-R\&D policy measures in achieving the government's energy objectives. Generally speaking, it is believed in Australia that government funding for energy research, development, and demonstration projects can only be justified when the private sector receives insufficient commercial incentive to undertake such work. 


\section{RNTITIES RESPONSIBLE FOR ENERGY R\&D}

\subsection{HISTORICAL ROLE OF AUSTRALIAN GOVERNMENT}

After Australia gained self-government in 1901, numerous Commonwealth government scientific organizations were established. The Science and Industry Research Act was passed in 1926, leading to the establishment of the Council for Scientific and Industrial Researc', which in 1949 became the Commonwealth Scientific and Industrial Research Organization (CSIRO). Since its inception, the organization has been responsible for many new scientific developments, particularly in mining and agriculture. The CSIRO is now Australia's largest scientific research establishment, employing over 7500 people and consuming more than a third of the total government science budget. This scientific organization carries out research in all areas but nuclear energy. The CSIRO spends more than a third of its annual budget of over $\$ 300$ million on agricuitural research, while mineral and energy research receives less than a sixth of the total budget.

Nonnuclear energy research was expanded in 1981, following the recommendations of the National Energy Research, Development and Demonstration Council (NERDDC). Research projects in solar energy, hydrogen production, environmental and structural chemistry in support of coal and synthetic fuel production, and characterization of trace elements in oil shales and coals were given new emphasis. Major new projects were also initiated, including studies of oil shale chemistry, coal gasification, the carbon monoxide/steam reaction for synthesis of liquid hydrocarbons, and alternative uses of coal.

\subsection{CURRENT ROLES AND RESPONSIBILITIES OF GOVERNMENT AGENCIES}

Summary. Energy research and development bv the Australian government is carried out under two ministries, Science and Technology and Resources and Energy. The Minister for Sxience and Technology oversees the activities of the Department of Science and Technology, the Australian Seience and Technology Council (ASTEC), and the CSIRO. The Minister for Resources and Energy heads the Department of Resources and Energy and is responsible for work carried out under the Australian Atomic Energy Commission (AAEC), the Bureau of Mineral Resources (BMR), and the National Energy Research, Development and Demonstration Council. The reporting relationships of these organizations are shown, respectively, in Figs. 1 and 2. The activities of all these organizations except the AAEC and the BMR are described below.

Depurtment of Science and Technology. Scientific research activities are coordinated and overseen by the Department of Science and Technology, which was formed from two separate depa:tments in 1981. The department, with a total budget of $\$ 574.2$ million for the 1984 financial year, is responsible for a number of Australia's major scientific bodies, such as the Bureau of Meteorology, the Antarctic Division, and 


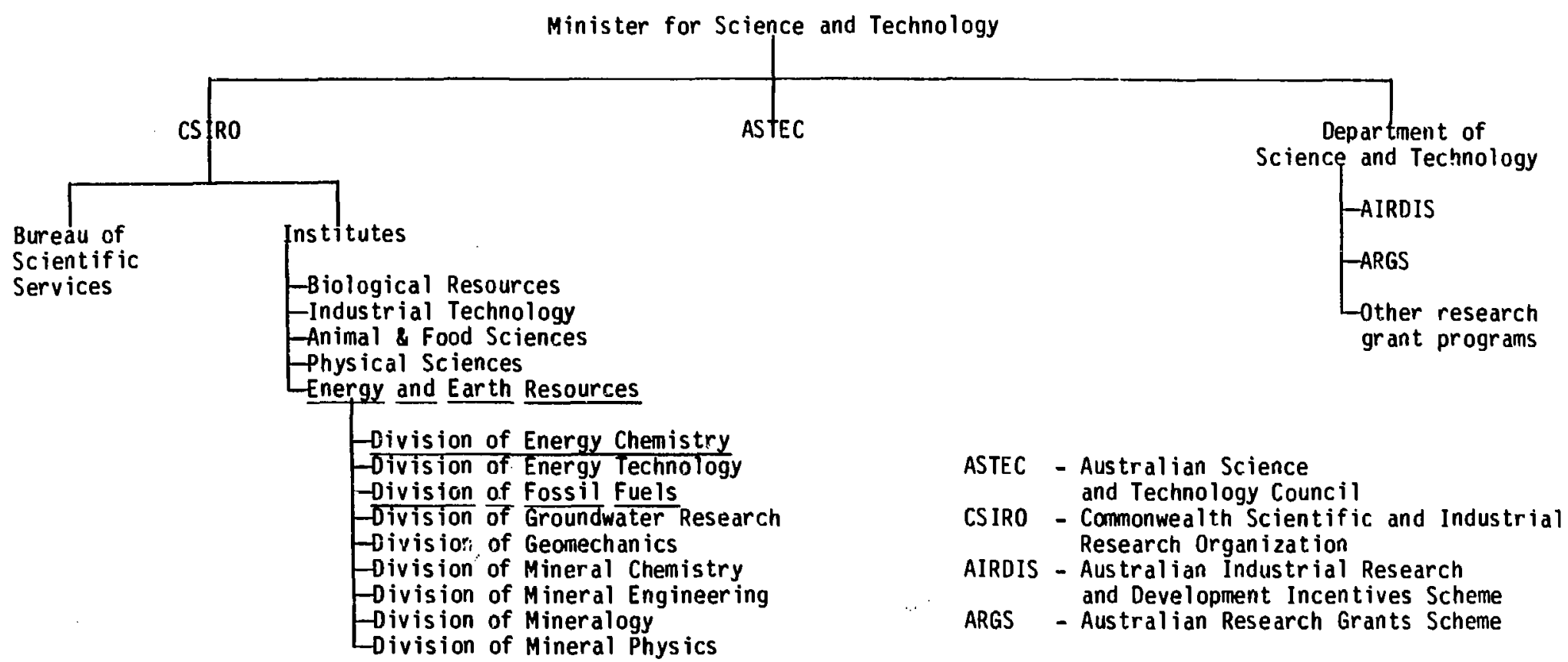

FIGURE 1 Reporting Relationships for Energy Aetivities Carried Out under the Minister for Seience and Technology 


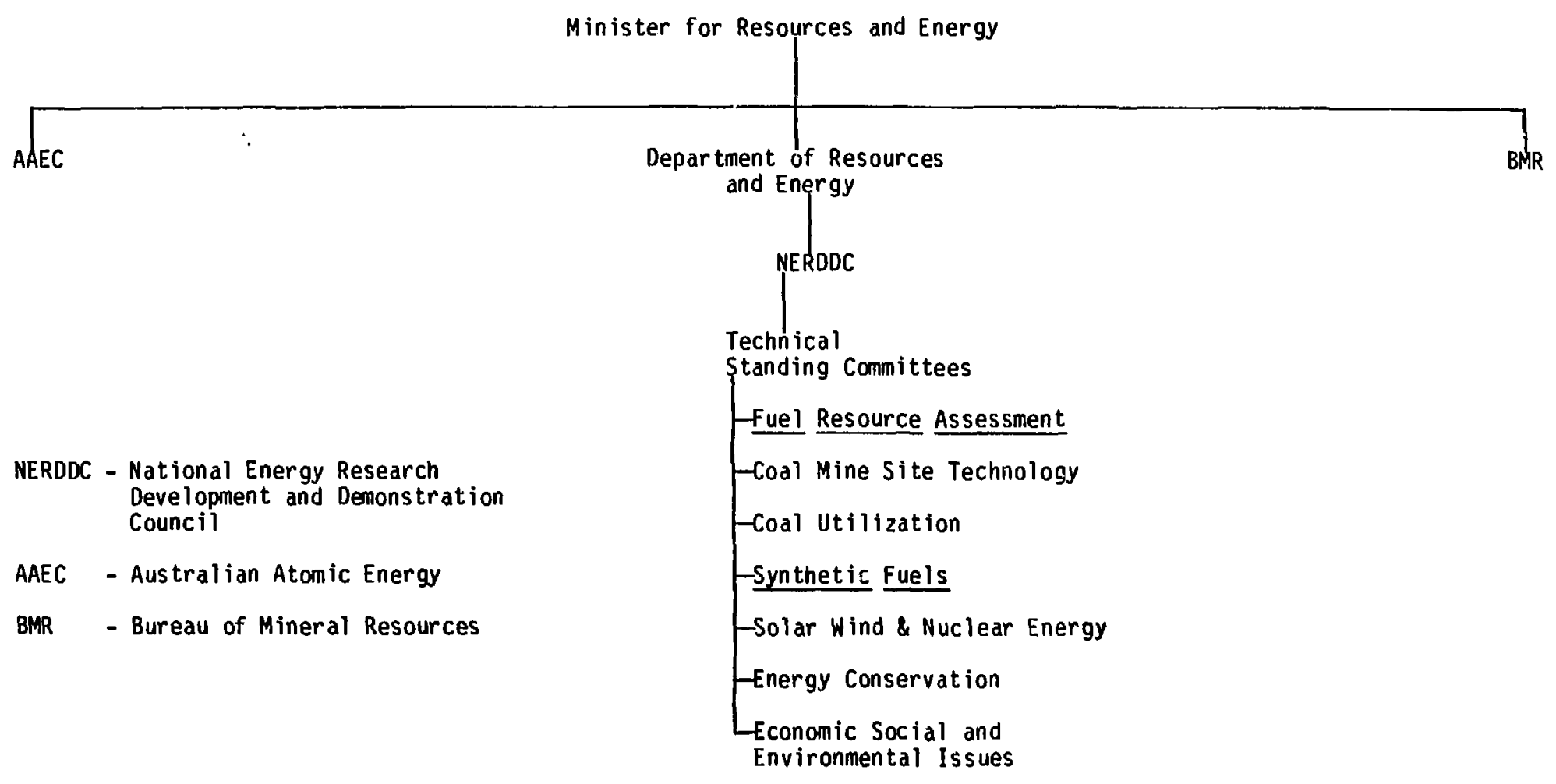

FIGURE 2 Reporting Relationships for Energy Activities Carried Out under the Minister for Resources and Energy 
others. This department is also the main source of policy advice to the minister and is responsible for the government's major industrial innovation and technology development programs. It administers a number of grant programs for basic research, missionoriented research, and industrial research.

Australian Seience and Technology Council (ASTEC). The ASTEC is the prime source of science and technology policy advice to the government and is directly responsible to the Minister for Science and Technology.

Commonwealth Scientific and Industrial Researah Organization (CSIRO). The CSIRO is responsible for planning and execution of a comprehensive program of general scientific research on behalf of the Commonwealth of Australia. The organization reports to the Minister for Seience and Technology. Research is carried cut in five institutes; energy research is conducted in the Institute of Energy and Earth Resources and is directed toward development of energy resources particularly relevant to Australia.

The Institute's Division of Fossil Fuels conducts research on coal pyrolysis and direct liquefaction. The Division of Energy Chemistry's ehief research areas include extraction of oil from shale and indirect coal liquefaction. Oil shale conversion R\&D is also conducted by the Divisions of Mineral Chemistry and Mineral Engineering. Other energy work is carried out in the Division of Energy Technology.

National Energy Researah, Development and Demontration Council (NERDDC). The National Energy Research, Development and Demonstration Council advises the Minister for Resources and Energy on the development and coordination of a national program of energy research, development, and demonstration in Australia. The NERDD program funds all sectors as distinct from the Australian Research Grants Scheme (A.RGS), which funds only nongovernment institutions, and the Australian Industrial Research and Development Incentives Scheme (AIRDI), which funds industry.

\subsection{STATE GOVERNMENT SPONSORSHIP OF R\&D}

The state governments are all heavily involved in science and technology development. In the past this has been mainly limited to agricultural research and extension services and medical research, but more recently it has extended to the support of high-technology development. All the states are moving strongly into this area by establishing technology ministries, technology parks, innovation centers, special technology funds, and information services. 


\subsection{NONGOVERNMENT COOPERATION IN R\&D}

1. Production sectors (industry).

2. Universities. The universities receive much of their funding for basic research thrcugh the Australian Research Grants Seheme (ARGS). However, the funding for this (\$22.4 million in 1984) is considered fas too low to support an adequate level of pure research in the country.

3. Seientific and technical associations. 


\section{AUSTRALIA'S ENERGY R\&D PROGRAM}

\subsection{BACKGROUND}

The National Energy Research, Development and Demonstration Council was established in 1978 and is responsible for the NERDD program. Only projects directly related to energy are supported by this program. Projects with broader industrial consequences are not normally supported. Moreover, the program does not sponsor innovation activities beyond the RD\&D phases, such as product development and marketing. No data are available on numerical long-range goals, but see Sec. 1.3 for energy policy objectives.

\subsection{CURRENT PRIORITIES}

In assessing the potential contribution of advances in each of the various energy technology areas, the NERDDC considers the following factors:

- Potential impact on the domestic supply of and demand for liquid Fuels, including substitution of one fuel for another;

- Australia's natural resource endowment;

- Economies of technologies under consideration, including the impacts of these technologies on the competitiveness of Australisn energy exports;

- The role of $R \& D$ in alleviating supply disruptions;

- Maturity and commercial potential of the various technologies;

- The time scale for research, development, or demonstration projects and resources they require; and

- Regional, institutional, social, and environmental implications of a particular technological advance.

The NERDDC has assigned various energy technology R\&D areas certain broad priority rankings, which take into account government policy objectives, perceptions of energy supply and demand, and advances in energy technology. These priority rankings are summarized below.

High-Priority R\&D Areas

- Energy conservation technologies related to liquid fuels, inclucing those in fields where specifically Australian or regional conditions are important. 
- Production of liquid hydrocarbon fuels from natural gas or from synthesis gas derived from coal or natural gas, including areas such as catalysts for production of middle distillates.

- Technology of exploration, assessment, and recovery of oil and gas, with emphasis on resource ass essment.

- Improvements in coal combustion technology, particularly with regard to the characteristics of Australian coals and local conditions.

- Ir. ved coal productivity, particularly by reducing operational p . . isms at increased depth and enhancing seam recovery, and by increasing efficiency in beneficiation plants.

\section{Medium-Priority R\&D Areas}

- Production of liquid fuels from oil shale and from coal by hydrogenation or pyrolysis, a priority that includes the characterization of Australian feedstocks, process evaluation, and catalyst studies.

- Energy conservation related to nonliquid fuels; particularly in industry and in buildings.

- Coal gasification.

- Active and passive solar energy and wind energy, with emphasis on achieving cost-effectiveness in remote applications.

- Coal carbonization, a technological priority consisting largely of evaluation of coals to complement industry-funded work.

- Improvement in techniques for the exploration and assessment of coal and oil shale resources, with particular regard to reducing costs.

- Methanol, with particular regard to end use and distribution problems.

- Ethanol, with emphasis on processes showing strong promise for reducing production costs and on effluent treatment.

- Energy storage, particularly for remote areas.

- Nuclear waste management. 


\section{Low-Priority R\&D Areas}

- In-situ coal gasification.

- Magnetohydrodynamics.

- Vegetable oils, with regard mainiy to potential applications.

- Production of methane from biomass feedstocks.

- Production of liquid and gaseous fuels by pyrolysis of wastes.

- Development of electric vehicles.

- Nuclear fusion.

- Use of hydrogen as a fuel.

- Wave, tidal, ocean thermal, and geothermal energy.

\subsection{CRITERIA FOR FUNDING R\&D PROJECTS}

Criteria used in assessing potential new projects for funding under the NERDD program relate to the following considerations:

1. Energy supply (ability to save liquid fuels or enhance supply);

2. Technology (technological feasibility, presence of necessary infrastructure, merit over an existing technology, or another new technology doing the same job, etc.);

3. Economics (benefits and costs, market penetration potential, industry readiness, ete.);

4. Social effects (social factors influencing energy demand, public acceptance of new technologies);

5. Environment (ability to advance environmental control technologies or knowledge of environmental impacts of extraction, conversion, or use of energy);

6. International interest (scope for international sollaboration to enhance cost savings, information sharing, and optimal use of scientific talent); and

7. Technology transfer (potential to become commer..ally viable). 


\subsection{CURRENT FUNDING LEVELS}

The NERDD program gets funds from two sources: The Energy Research Trust Account (ERTA), which is included in departmental appropriations in the annual budget, and the Coal Research Trust Account (CRTA) into which funds accrue from a levy on coal production and are by law dedicated to coal research.

Seven technical standing committees carry out activities under the NERDD program. Committees and the subprograms of each committee, along with the cumulative funding of the activities from inception of the NERDD program (1978) through 1985, are summarized below.

1. Technology of Fuel Resource Assessment (\$7.8 million)

- Petroleum resource recovery techniques (\$1.37 million)

- Petroleum resource assessment

- Petroleum exploration techniques

- Coal and oil shale exploration techniques

- Coal and oil shale rescurce assessment

2. Coal Mine Site Technology (\$33.9 million)

- Prediction of seam anà strata conditions

- Underground mining

- Surface mixing

- Beneficiation

- Handling, storage, and transportation

- Environmental aspects

3. Technology of Coal Utilization (\$19.2 million)

- Coal combustion: pulverized fuel

- Coal combustion: fluidized bed

- Assessment of coals

- Carbonization 
- Coal utilization in metallurgical and manufacturing processes

- Coal gasification

- Coal utilization: environmental aspects

4. Technology of Synthetic Fuels (\$25.8 million)

- Methanol (\$0.7 million)

- Ethanol (\$6.2 million)

- Coal liquefaction ( $\$ 14.3$ mililion, or $56 \%$ of funds committed to date to synthetic fuels)

- Oil shale ( $\$ 1.9$ million)

- Vegetable oils (\$0.07 million)

- Biomass (\$0.01 million)

- Fuel conversion catalysts (\$2.0 million)

5. Solar, wind, and nuclear energy (\$19.8 million)

- Solar thermal applications

- Solar collector technology and testing

- Photovoltaics

- Wind energy technology

- Remote area power supply

- Energy storage

- Nuclear energy

- Electric vehicles

- Long-term alternative energies

6. Energy conservation technology ( $\$ 15.3$ million)

- Agriculture

- Built environment 
- Industry

- Transport systems

- Vehicles

7. Economic, social, and environmental issues (\$4.3 million)

- Environmental subprogram

- Social and economic subprogram 


\section{FOSSIL ENERGY RESERYES}

Australia is characterized by very limited oil reserves and huge reserves of coal, shale, and natural gas. Though domestic crude oil production is expected to decline considerably over the next decade, Australia has abundant fossil resources suitable for the development of synthetic fuels. These resources include natural gas, oil shale, black coal, and brown coal.

Natural gas reserves stand at $3.7 \cdot 10^{9}$ barrels of oil equivalent (boe), including major deposits in Bass Strait, the Cooper Basin, and the Nor shwest Shelf. Total domestic consumption of natural gas through 1994 is estimated at. $.1 \cdot 10^{9}$ boe, and another $200 \cdot 10^{6}$ boe are expected to be exported as liquefied natural gas from the Northwest Shelf during the same period. Prospects for further natural gas discoveries appear to be good.

Most of Australia's oil shale reserves (see Table 1) are in Queensland, where there is evidence of in-ground resources of about $27 \cdot 10^{9} \mathrm{bbl}$ of shale oil. Most of these deposits are along the east coast.

Recoverable reserves of black coal (see Table 2), including coking and steaming coals, are estimated at slightly more than $30 \cdot 10^{9}$ t, located primarily near the east coast of New South Wales and Queensland. Assuming that the yield of coking coal is maximized using established coal preparation and blending techniques, the marketable resource is estimated at just over $23 \cdot 10^{9}$ t. At current production ratas of around $130 \mathrm{t} / \mathrm{yr}$ (with approximately half of this total exported), the calculated marketable reserves would last about $180 \mathrm{yr}$. Estimated reserves of Australian black coal are very much larger than the recoverable reserves.

Australia also has substantial reserves of brown coal (Table 3), mostly located in Victoria's Latrobe Valley, with smaller deposits in South Australia, Western Australia, and Tasmania. The content of Victorian brown coal is characterized by high moisture, low ash, and low sulfur. A 1983 study by the Vietorian Brown Coal Council estimated the total in-situ resource at $202 \cdot 10^{9}$ t. Total usable reserves, based on current extraction technology, were estimated at $54 \cdot 10^{9} \mathrm{t}$, including coals suitable for power generation, production of

TABLE 1 Au::ralian In-Situ Shale Oil Reserves

\begin{tabular}{lc}
\hline \multicolumn{1}{c}{ Region } & $\begin{array}{r}\text { Regerves } \\
\left(10^{9} \text { bbl }\right)\end{array}$ \\
\hline Condor & 9.65 \\
Duaringa & 3.72 \\
Lormead & 0.74 \\
Nagoorin & 2.65 \\
Nagoorin South & 0.47 \\
Stuart & 2.51 \\
Rundle & 2.65 \\
Yaamba & 2.82 \\
Julia Creek & 1.70 \\
Total & 26.91 \\
\hline
\end{tabular}

Source: Central Pacific Minerals NL. Annual Report 1983, Julia Creek oil shale, CSR, November 1982 . 
TABLE 2 Black Coal Resources of Australia

\begin{tabular}{|c|c|c|c|c|c|c|}
\hline \multirow[b]{2}{*}{$\begin{array}{c}\text { Type of } \\
\text { Coal }\end{array}$} & \multicolumn{6}{|c|}{ Resources $\left(10^{9} t\right)$, by Region } \\
\hline & $\begin{array}{l}\text { New South } \\
\text { Wales }\end{array}$ & Queensland & $\begin{array}{l}\text { Western } \\
\text { Australia }\end{array}$ & $\begin{array}{c}\text { South } \\
\text { Australia }\end{array}$ & Tasmania & Total \\
\hline \multicolumn{7}{|l|}{$\begin{array}{l}\text { Recoverable } e^{a} \\
\text { Raw Coal }\end{array}$} \\
\hline $\begin{array}{l}\text { Coking } \\
\text { Noncoking } \\
\text { Total }\end{array}$ & $\begin{array}{r}2.740 \\
9.382 \\
12.122\end{array}$ & $\begin{array}{r}8.007 \\
10.140 \\
18.147\end{array}$ & $\begin{array}{c}- \\
0.482 \\
0.482\end{array}$ & $\begin{array}{c}- \\
0.150 \\
0.150\end{array}$ & $\begin{array}{l}- \\
0.246 \\
0.246\end{array}$ & $\begin{array}{l}10.747 \\
20.400 \\
31.147\end{array}$ \\
\hline Market ableb & & & & & & \\
\hline $\begin{array}{l}\text { Coking } \\
\text { Noncoking } \\
\text { Total }\end{array}$ & $\begin{array}{l}5.400 \\
3.150 \\
8.550\end{array}$ & $\begin{array}{r}5.560 \\
8.275 \\
13.835\end{array}$ & $\begin{array}{l}- \\
0.482 \\
0.482\end{array}$ & $\begin{array}{c}- \\
0.150 \\
0.150\end{array}$ & $\begin{array}{c}- \\
0.147 \\
0.147\end{array}$ & $\begin{array}{l}10.960 \\
12.204 \\
23.164\end{array}$ \\
\hline
\end{tabular}

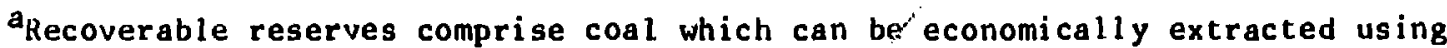
current mining cechniques.

barketable connages calculated on the basis of the use of coal preparation and blending techniques to optimize coking coal yield.

Source: Joint Coal Board, Black Coal In Australia 1983-84. 
TABLE 3 Victorian Brown Coal Reserves

\begin{tabular}{lc}
\hline \multicolumn{1}{c}{ Type of Reserve } & $\begin{array}{c}\text { Reserves } \\
\left(10^{9} \mathrm{r}\right)\end{array}$ \\
\hline $\begin{array}{l}\text { Total Resource } \\
\text { Usable Reserves } \\
\text { Suitable for all purposes }\end{array}$ & 24.172 \\
$\begin{array}{l}\text { Suitable for hydrolique- } \\
\text { faction, pyrolysis, char } \\
\text { production, gasification }\end{array}$ & 10.175 \\
$\begin{array}{l}\text { Suitable for gasification } \\
\text { Reserves available for }\end{array}$ & 19.390 \\
development & 31.000 \\
\hline &
\end{tabular}

pulverized dried urown coal, briquetting, carbonization, liquefaction, and gasification. Total reserves available for future development have been estimated at $31 \cdot 10^{9}$ t. At current production rates of $35 \mathrm{t} / \mathrm{yr}$ (used mainly for power zeneration), the readily available reserves would last nearly $1000 \mathrm{yr}$. 


\section{OIL, GAS, SHALE, AND COAL LIQUIDS R\&D}

\subsection{RATIONALE FOR OIL, GAS, SHALE, AND COAL LIQUIDS RESEARCH}

Although current crude oil prices are low enough to discourage a major cornmitment worldwide to the production of synfuels from natural gas, oil shale, or coal, the Australian government has resolved to develop these technologies for the following reasons:

- Australia's self-sufficiency in oil is expected to fall off considerably in the 1990s. Unless new oil reserves are discovered, the country might produce less than $44 \%$ of its crude oil needs by 1994.

- Oil supplies are expected to be tighter and oil prices fixed in the 1990s.

- A viable synfuels industry could provide opportunities to convert Australia's abundant resources of natural gas, coal, and oil shale to export income.

\subsection{GOVERNMENT POLICIES IN SUPPORT OF OIL, GAS, SHALE, AND COAL LIQUIDS DEVELOPMENT IN AUSTRALIA}

The following policies are in place to facilitate the development of oil, gas, shale, and coal liquids when their technical and economic viability is established.

Domestic Marketing/Pricing. A producer of synfuels would have the right, over the life of the project, to sell its products in the domestic market to buyers of the producer's choice and, in the case of syncrude, at prices no less favorable than those applying to newly discovered conventional oil (subject to the usual quality comparisons).

Overseas Marketing/Product Sharing. Consideration will be given on a casespecific basis to proposals for sharing with foreign investors and technology holders the liquid products of synthetic fuel projects undertaken in Australia with Australian partners. There is not necessarily a one-to-one relationship between the proportion of financing provided by a foreign technology holder or foreign investor and the proportion of product that might be exported by that entity's venture. Thus, a foreign investor holding 50\% equity in a synthetic fuels venture is not entitled automatically to export a corresponding share of the venture's output.

Environmental Policy. Proposals for synthetic fuel projects that involve the application of Commonwealth government powers, such as approvals for product exports or for overseas borrowing of capital, are required to be assessed under the Environmental 
Protection (Impact of Proposals) Act. One objective of this act/is the early identification and resolution of environmental problems of any major developrnent.

Foreign Investment. As a general rule, new mining projects are permitted only if a minimum of 50\% Australian equity is present and Australian interests hold 50\% of the voting strength on the project's controlling body. For foreign investment purposes, however, synthetic fuel production is considered to be a minerals processing activity. As such, policy aims to maximize opportunities for significant Australian participation in the ownership and control of new synthetic fuels projects. Thus the policy does not place a fixed percentage on Australian participation, but stipulates that consultations are to be held with concerned parties to attain an appropriate level of Australian participation to meet the policy aim. In this process, recognition is given to the needs of synthetic fuel projects for large amounts of capital and advanced technology not available domestically.

With respect to pilot plant development, consideration has been given to foreign investment of up to $100 \%$, subject to the following understanding:

- Any proposals for development of the demonstration and commercial plant stages require separate examination under the foreign investment policy, and, at that time, Australian equity and control in the demonstration and commercial plants is expected, according to the general policy outlined above.

- Suitable arrangements for technology transfer must be provided.

On this basis, approval was given for $100 \%$ Japanese equity in the Brown Coal Liquefaction (Victoria) Pty. Ltd. proposal to construct a brown coal liquefaction pilot plant in Victoria's Latrobe Valley.

Banking and Exchange Controls. Assurances have been given that certain iargescale projects will be free from future adverse changes to controls on overseas borrowings if such changes might prejudice plans for funding, subject to the following conditions:

- Projects must involve estimated capital expenditure exceeding $\$ 500$ million;

- Applicants must demonstrate a very high probability that the project will commence within three years;

- No assurances will be given with respect to borrowings with a repayment term of less than four vears; and

- Applicants must reach satisiuctory agreement with the Reserve Bank on the timing of dray-downs of overseas borrowings. 
Technology Transfer. Foreign developers of pilot plants in Australia are expected to open lines of communication, including entering into secrecy agreements if necessary, with Australian firms interested in future participation in the venture so that these firms can gain knowledge on the progress and future potential of the project. Australian firms participating in demonstration and commercial plants are to be granted access to use all technology on reasonable terms and conditions with the unequivocal assurance that all pariners in the joint venture would use the technology on the same terms. Should the foreign technology holders involved in a pilot plant development in Australia decide not to commit themselves to the demonstration and/or commercial plant stages, adequate opportunities are to be made available for interested Australian firms to gain access on reasonable terms and conditions to use of the technology developed for the project -- thus assuring the right of the Australian firms to investigate the potential for applying the technology to some other venture in Australia. The above policies regarding technology transfer currently apply to the Brown Coal Liquefaction pilot plant project.

R\&D. Support for synthetic fuels R\&D under the NERDD program is aimed at developing an understanding of the properties and processing characteristics of indigenous feedstocks, especially coal and oil shale, as well as more detailed understanding of the technology involved in conversion of coal, oil shale, natural gas, and biomass feedstocks to transport fuels. The National Energy Research, Development and Demonstration Council is adopting a "top-down" strategy aimed at supporting and completing ongoing private-sector activities.

The NERDDC considers natural gas conversion a high-priority area. Direci coal liquefaction, oil from shale, ethanol, and methanol are considered niedium-priority areas, while vegetable oils and biomass conversion to methane are likely to become low-priority areas.

Where appropriate, domestic $R \& D$ is complemented by international cooperative projects. These cooperative efforts are described in Sec. 7 of this report.

\subsection{RESEARCH PROGRAMS AND FUNDING}

Funds totaling $\$ 25.8$ million have been committed to synthetic fuels $R \& D$ since 1978 under the NERDD program. Of these funds, $\$ 14.3$ million were for direct liquefaction, $\$ 1.9$ million for oil from shale, and $\$ 2.6$ million for natural gas conversion/indirect coal liquefaction. The remaining $\$ 7.0$ million went to $R \& D$ on methanol, ethanol, and vegetable oils. Following is a summary of current and recent activities in coal liquefaction, oil shale, and natural gas conversion.

\subsubsection{Coal Liquefaction}

Funds totaling $\$ 16.9$ million have been committed to date to coal liquefaction $R \& D$ under the NERDD program. The program has been directed toward the three main routes for production of liquid fuels from coal: hydroliquefaction, pyrolysis, and indirect liquefaction. 
Hydroliquefaction. Hydroliquefaction R\&D programs are aimed at characterization of Australian coals, investigation of reaction mechanisms and kinetics, and evaluation of strategies for conversion of Australian coals to liquid products. Routine testing of Australian coals for their hydroliquefaction potential has been undertaken, and emphasis is now to be placed on processing strategies. Results from a recent upgrading study indicate that liquids derived from black coal can be refined to specification transport fuels; investigations on liquids from Victorian brown coal are in progress. A study to collate the results of the program to date and to piace the results in perspective with overseas $R \& D$ programs is underway.

Though the Australian government contributes no funds to the 50-t/d brown coal liquefaction pilot plant being developed by the Japanese government in Victoria state, it is cooperating in the project through foreign investment approval, duty-free import of plant equipment, and environmental impact approval. The Victorian government is providing coal supply, a scrviced site for the plant, and engineering assistance.

Other hydroliquefaction activities have included a joint coal-to-oil feasibility study by Atstralia and West Germany. The results indicated that the potential returns on investment were not in themselves sufficient to justify commercial development.

Pyrolysis. Pyrolysis studies at CSIRO Division of Fossil Fuels have been aimed at evaluating the long-term operation of a fully integrated $20 \mathrm{~kg} / \mathrm{h}$ flash pyrolysis unit comprising pyrolyser, a char-burning heat generator, heat-transfer system, ind tarhydrogenator. An earlier independent evaluation of the process concluded that the process has no economic or technical advantages over technologies proven at a larger scale overseas. Funding for pyrolysis studies is not envisaged beyond the present commitment.

Indirect Liquefaction. Indirect liquefaction studies carried out by the CSIRO in conjunction with Flinders University and private industry are aimed at the development of selective catalysts (modified ZSM-5 and Fischer-Tropsch catalysts) for production of liquid transport fuels. The Flinders University program has led to two promising catalysts, which are being further evaluated by private industry. The first is a FischerTropsch catalyst having high selectivity to linear $\mathrm{C2}-\mathrm{C} 8$ alkenes; the second is an isomerization catalyst that coverts the $\mathrm{C2}-\mathrm{C8}$ alkenes to branched hydrocarbons suitable for gasoline. Most of the indirect liquefaction program is also applicable to natural gas conversion.

\subsubsection{Oil Shale}

Recently, attention has been directed toward the large oil shale deposits in Queensland, including detailed evaluation of the Condor and Rundle deposits; studies on deposits at Julia Creek, Yaamba, and Stuart (pre-feasibility studies); and studies on deposits at Lowmead, Nagoorin, and Duaringa (resource assessments). A joint feasibility study on the production of liquids from the Condor oil shale deposit was recently 
completed by the Japan Australia Oil Shale Corporation (JAOSCO). That corporation and two regional companies (Southern Pacific Petroleum and Central Pacific Minerals) have recently shipped screened and crushed oil shale to Japan to be used in a proposed 300-t/d pilot plant retort. The two companies have also had an agreement with Esso Exploration and Production Australia, Inc., to carry out a joint feasibility study on the production of liquid fuels from the Rundle oil shale deposit.

Funds totaling $\$ 1.9$ million have been committed to oil shale $R \& D$ under the NERDD program. Support under the program has been additional and complementary to private-sector support for oil shale R\&D, which has included confidential work at Australian universities and the CSIRO and has been supported by Southern Pacific Petroleum/Central Pacific Minerals and Esso. This work will provide information required for the economic and technical assessment of future processing of Australian oil shales.

Projects supported under the NERDD program include a program at the CSIRO Division of Energy Chemistry aimed at evaluating the relative processing characteristics of selected Australian oil shales, including bench-scale retorting trials and combustion testing of spent shales. A concept for Julia Creek oil shale began in 1985. The oil shale R\&D program has also included upgrading studies, which have determined the conditions required to upgrade raw shale oil from Julia Creek to speeification transport fuels.

\subsubsection{Natural Gas}

Australian interest in natural gas conversion has been directed toward the evaluation of octane improvers, including methanol, mixed alcohols, and methyltertiary butyl ether (MTBE), as well as research and development aimed at the development of improved catalysts for the production of specification transport fuels.

Australia's interest in octane enhancers is a result of the decision to phase in lead-free gasoline for motor vehicles. Lead-free gasoline became available in mid-1985, and it is now mandatory that all new gasoline-powered motor vehicles be designed to run on it. A division of Broken Hill Proprietary Company (BHP), BHP Petroleum, has conducted a study aimed at evaluating options and prospects for octane enhancers in Australia. The program has included engineering and cost studies as well as marketing investigations.

Under the NERDD program, a series of studies has been conducted on the use of methanol as a gasoline extender. The results have indicated that a number of economic and other problems remain to be overcome before methanol is likely to be used as a gasoline extender in Australia.

Natural gas conversion $R \& D$ in Australia is directed mainly toward the development, characterization, and testing of improved catalysts for the production of liquid fuels. This work includes a major project conducted and funded by BHP as well as NERDD projects at BHP (zeolite catalysts), at the CSIRO Division of Materials Science (zeolite and Fischer-Tropsch catalysts), and at Flinders University (Fischer-Tropsch catalysts). 


\subsection{LIST OF CURRENT PROJECTS}

Current projects in oil, gas, shale, and coal liquids $R \& D$ are carried out by government in-house research departments, universities, and private industry. Funding sources are the NERDD program, the CSIRO, and the Coal Corporation of Victoria. Projects are listed below under their funding sources. Where funding sources are not identified, they are listed separately. Furtĩier details of these projects are available.

1. Federal government-funded projects

- NERDD program

- Economic feasibility of producing liquid transport fuels from Australian coals $(\$ 225,350)$

- Liquid fuels by hydroliquefaction of Australian coals using discardable catalysts $(\$ 979,800)$

- Continuous coal hydrogenation -- processes and products $(\$ 4,387,162)$

- Catalytic coal hydrogenation for automotive fuels $(\$ 722,500)$

- Development of new Fischer-Tropsch eatalysts (\$424,780)

- Modeling of coal liquefaction reactions $(\$ 78,000)$

- Direct hydrogenation of brown coal in a continuous-flow catalytic reactor

- New routes to methanol $(\$ 182,643)$

- Lubricating oil potential of low-temperature coal tars $(\$ 48,715)$

- Properties of chars $(\$ 24,500)$

- In-situ gasification in Australia (\$92,561)

- CSIRO, Division of Energy Chemistry

- Carbon monoxide/steam (Kolbel-Engelhardt) reaction for low-hydrogen synthesis gas

- Fischer-Tropsch process for methane-derived synthesis gas

- Gasification studies $\mathbf{( \$ 2 0 , 6 7 5 )}$ 
- CSIRO, Division of Fossil Fuels

- Coal conversion

- Demineralization and new uses for coal

- Examination of reactive surfaces by $x$-ray photoelectron spectroscopy

- Flash pyrolysis

- Fossil fuel characterization

- Fossil fuel conversion mechanisms

- Fouling and corrosion by ash in combustion systems

- Microscopy in coal hydrogenation and combustion studies

2. Coal Corporation of Victoria

- Brown coal liquefaction

- Catalytic effects of inorganic constituents in the direct hydrogenation of brown coal $(\$ 380,852)$

- Effects of a coal liquefaction plant on the atmospheric environment

- Microbial oxidation of polynuclear compounds

- Carbon-monoxide attack on Victorian brown coal $(\$ 47,577)$

3. State Electricity Commission of Queensland; Queensland Department of Commercial and Industrial Development: combustion of char in power station boilers

4. Universities

- Kinetics of brown coal hydroliquefaction (Monash University)

- Phase behavior of mixtures containing hydrogen, methane, ethane, or carbon monoxide (University of Melbourne) 


\section{INTERNATIONAL COLLABORATIONS IN OIL, GAS, SHALE, AND COAL LIQUIDS R\&D}

\subsection{RATIONALE AND ORIENTATION}

A relatively advanced industrial country with a small population, Australia needs access to a wider range of scientific and technological knowledge than it is capable of producing itself. As a result, the country has always drawn heavily on overseas sources to meet its scientific and technological needs.

Australian participation in international cooperative science and technology activities proceeds largely on the basis of informal decisions made by individual scientists or organizations in government, industry, or academia in the pursuit of their particular objectives. Thus the greater part of international cooperation and exchange in science and technology takes place outside any government programs specifically directed toward promotion of such activity. The Australian Science and Technology Council (ASTEC) believes this informal "decentralized" approach is the most effective way for Australia to receive the benefits of international exchange. The ASTEC reviews ongoing activities under established agreements and reviews the operation of overseas visitation programs for those government agencies with major science and technology programs. It performs these reviews to ensure that available resources are used most effectively in gaining access to international science and technology.

Until the end of World War II, Australia's closest scientific links were with Britain. During the war, however, the closer political, industrial, and military alliance with the United States demonstrated advantageous opportunities for greater collaboration with the U.S. The transformation of the Australian economy since the war and the changing pattern of Australia's international trade extended international scientific relationships beyond the traditional partners. Because of these developments, Australia now participates in scientific and technological exchanges and conferences with a large number of countries and in a wide range of fields.

\subsection{AGENCIES FOSTERING COOPERATIVE R\&D}

\subsubsection{Australian Agencies}

The Commonwealth's main ageneies fostering scientific collaboration are the Commonwealth Science Council (CSC), which aims to increase national capabilities in the use of science and technology for economic and social development, and the Commonwealth Fund for Technical Cooperation, which of ten assists in finaneing CSC projects.

\subsubsection{International Organizations}

A substantial part of Australia's participation in international programs in science and technology follows from its membership in intergovernmental organizations 
or from other intergovernmental arrangements. The major intergovernmental arrangements are promoted through (1) the United Nations; (2) the Orgarization for Economic Cooperation and Development (OECD); (3) the Commonwealth and its organizations; and (4) the Defense Technical Cooperation Program with the U.S., U.K., Canada, and New Zealand. These and other multilateral organizations, which receive contributions from Australia, provide forums for discussion, exchange of information, and setting of international scientific and technical standards. Australia has contributed $\$ 753,000$ since 1979 to the OECD International Energy Ageney for projects in energy technology systems analysis, commercial-building energy monitoring, solar-collector performance testing, economic assessment of coal, and a coal mining technology clearinghouse.

In addition, Australia directs a large part of its participation in multilateral collaborative programs toward developing countries, particularly under the auspices of the Economic and Social Commission for Asia and the Pacific, the World Health Organization, and the Commonwealth and its organizations. Australia is also a contributor to the financing sources of such programs, including, for example, the United Nations Development Program.

Australia maintains a number of representatives in overseas posts whose duties relate primarily to science and technology or closely related matters. The CSIRO functions as a liaison between Australia and other countries in matters of scientific research. The agency that maintains positions relevant to nonnuclear energy research is the Department of National Development and Energy, which has a minister at the OECD.

\subsection{BILATERAL AGREEMENTS}

\subsubsection{Existing Agreements}

Apart from the decentralized actions of its various agencies, the Australian government has several formal agreements with other countries covering collaboration in science and technology. Some of the agreements have the aim of stimulating gereral exchanges in science and technology; some relate to specific science and techriology areas; and some are directed to broad trade or cultural objectives, while including provisions for the encouragement of interaction in science and technology. Technological exchanges and collaborations, which attract much higher appropriations than do scientific exchanges, are encouraged under the more specific arrangements. Most of these agreements in recent years have related to energy $R \& D$ and are carried out under the Department of National Development and Energy as the cooperating Australian agency.

A number of current and recent specific bilateral agreements with Britain, the U.S., Japan, and West Germany - particularly those related to oil, gas, shale, and coal liquids $R \& D$-- are summarized below. Australia has also had cooperative agreements in science and technology with New Zealand, Canada, India, China, Mexico, and the Soviet Union. 
Britain. The scientific relationship between Britain and Australia has weakened in recent years. According to the ASTEC, Britain has demonstrated an increasing commitment to integration with Europe and has become less attractive as a center for postgraduate studies. Australia has become more involved in cooperation with the United States and other countries, and is increasingly interested in regional activities in the Pacific Basin and Asia. This weakening, however, has been from a position of great strength prior to World War II, so a great deal of cooperation has continued. One major collaborative effort between Australia and the U.K. is in the area of coal mining and utilization, to which the Department of National Development and Energy contributed approximately $\$ 219,000$ in $\mathbf{1 9 8 0 - 8 1}$ for collaborative programs with the U.K. National Coal Board.

United States. Scientific contact with the U.S. has been predominantly informal. However, several scientific agreements have been negotiated because of the legal considerations, large financial commitments, or major policy implications of the collaboration. Signed agreements relate to atomic energy, defense science information exchange, space communications, astronomical studies, and geological studies. The Australian Department of National Development and Energy also supports a program of cooperation with U.S. agencies. This program includes cooperation with the U.S. Department of Energy on coal extraction, processing, and conversion, and with the U.S. Bureau of Mines on the health, safety, and environmental aspects of coal technology.

Japan. The Department of National Development and Energy finances or contributes to the financing of several cooperative projects with Japan. These relate to solar energy and coal technology and include the Brown Coal Liquefaction Feasibility study by the Vietorian Brown Coal Council and the Nippon Brown Coal Liquefaction Company.

Federal Republic of Germany (FRG). An agreement on Scientific and Technology Cooperation was signed with West Germany in 1976. Scientific exchanges under the agreement are administered by Australia's Department of Science and Technology and the German Ministry for Research and Technology. The major areas of cooperation have been in solar energy, coal liquefaction, and geology. The Department of National Development and Energy, together with the state governments of Victoria, New South Wales, and Queensland, is funding a joint Coal-to-Oil Feasibility Study with the FRG Ministry of Research and Technology.

\subsubsection{Criteria for Future Bilateral Agreements}

Recent reviews of the operation of bilateral science and technology agreements in Canada and the United States have prompted ASTEC to review the operation of 
Australian bilateral agreements. The ASTEC has suggested criterla to be observed when entering into new science and technology agreements. The criteria are as follows:

- The potential partner country in an agreement should already possess scientific and technical excellence in fields of common interest.

- The potential partner country should possess speeial skills, iacilities, or experience which could benefit Australia.

- Formal agreements should be considered with countries whose political, cultural, or language barriers might otherwise prevent the development of informal contacts, as long as the considered country meets the other criteria.

- The bilateral agreement should receive adequate support from the Australian scientific and technical communities.

- There should be a clearly perceived extra benefit to be gained from establishment of a formal bilateral agreement with a partner country (above and beyond improving informal relations with that country).

- Scientific and financial resources should be available in Australia and in the partner country to support the agreement at a worthwhile level.

\subsubsection{Planned Agreements}

The Australian government is currently working with the U.S. DOE's Office of International Affairs to examine possible areas for cooperative $R \& D$. The following four areas have been identified as potential candidates: Synroc, brown coal combustion, oil shale, and information exchange.

\subsection{MULTLATERAL AGREEMENTS}

Most multilateral cooperation is through United Nations or Commonwealth bodies, which are important forums for interaction between Australia and Third World countries. Although some programs have clear-cut benefits for Australian science and technology, the predominant orientation is toward developing countries.

Through membership in such organizations as the International Council of Scientific Unions and the Organization for Economic Cooperation and Development, Australian scientists have become interested in the possible advantages of Australian collaboration in the use of expensive facilities through multilateral programs. Australia already participates in one "big science" project, the Anglo-Australian telescope, and involvement in other projects is under consideration. 


\section{INDUSTRIAL PARTICIPATION IN COAL LIQUIDS, OIL SHALE, AND NATURAL GAS R\&D}

\section{T.1 COAL LIQUIDS}

Hydroliquefaction R\&D programs are conducted by Australian Coal Industry Research Laboratories Ltd. (ACIRL) and BHP Co. Both of these companies operate laboratory-scale continuous reactor units. The refining characteristics of liquids produced in the ACIRL reactor are being evaluated by another company, Ampol Ltd.

The BHP Co. is also conducting indirect liquefaction studies aimed at developing selective catalysts for production of liquid transport fuels. This work is being carried out in conjunction with Flinders University and the CSIRO Division of Material Sciences. Another company, CSR Ltd., is investigating catalytic coal hydrogenation for automotive fuels. Coal conversion work by BHP, ACIRL, Ampol, and CSR is at least partially funded by the NERDD program. Projects being carried out under NERDD contracts are listed in Sec. 5.4.

The 50-t/d brown coal liquefaction pilot plant in the Latrobe Valley of Victoria is being constructed and will be operated by Brown Coal Liquefaction (Victoria) Proprietary Ltd. (BCLV), a wholly-owned subsidiary of Nippon Brown Coal Liquefaction Proprietary Ltd. The project is fully funded by the Japanese government.

\subsection{OIL SHALE}

Australian oil shale activities are carried out in conjunction with Japanese industry and in many cases are fully funded by the Japanese companies.

In 1981, Southern Pacific Petroleum (SPP) and Central Pacific Minerals (CPM) signed an agreement with the Japan Australia Oil Shale Corporation (JAOSCO) for a feasibility study on the production of liquids from the Condor oil shale deposit. The \$24 million (U.S. \$) study was financed by JAOSCO, whose shareholders comprise the Japan National Oil Corporation and 40 major Japanese companies. Also in 1981, SPP/CPM signed an agreement with Esso Exploration and Production Australia, Inc., to conduct a feasibility study on liquid fuels from the Rundle oil shale deposit. In July 1984, SPP/CPM entered into an agreement with the Japan Oil Shale Engineering Co., a separate consortium of 36 Japanese companies, to supply crushed oil shale for use in a 300-t/d pilot plant retort in Japan.

The same two Australian companies (SPP and CPM) are also working with CSIRO on using fluidized-bed techniques on a variety of Australian oil shales. This work is supported by the NERDD program and will provide information required for the economic and technical assessment of future processing of Australian oil shale.

The Yaamba oil shale deposit is being investigated by Peabody Australia Pty. Ltd. in collaboration with CSIRO. 


\subsection{NATURAL GAS}

The Broken Ifill Proprietary Company. Ltd. (BHP), Australia's largest publicly owned company, has a major project aimed toward development, characterization, and testing of improved catalysts for the production of liquid fuels. The basic technology used by BHP in commercially developing liquid fuels from natural gas was researched and patented by CSIRO. The process does not use the production of methanol as an intermediate step, but rather synthesizes hydrocarbon molecules directly from methane via butane. BHP spent $\$ 1$ million in 1984 on the gas-to-oil project. 


\section{SOURCES CONSULTED}

The information presented in this report was compiled entirely from the sources iisted below. No contact was made with representatives of the Australian government to obtain or verify this information.

Australian Dept. of Resources and Energy, Compendium of Australian Energy Research, Development and Demonstration Projects, No. 6 (Juse 1985).

Australian Dept. of Resources and Energy, National Energy Research, Development and Demonstration Program: Guidelines and Priorities for Grants (Feb. 1985).

Australian Dept. of Resources and Energy, Synthetic Fuels Research, Development and Demonstracion in Australia (Feb. 1985).

Australian Government Publishing Service, Australia's Mineral Exports: Coal, Canberra (1984).

Australian Seience and Technology Council, Australian Science and Technology in International Cooperation and Development Assistance, Canberra, Australian Government Publishing Service (May 1982).

Commonwealth Seientific and Industriail Research Organization, Division of Energy Chemistry Biennial Resecrch Report (1982-83).

Commonwealth Scientific and Industrial Research Organization, Energy, CSIRO Research for Australia, 2 (no date).

Ford, J., and J. Costello, with J.M.F. Keeney and M. Knipe, eds., Australian Technology: Past, Present, Future, Scientific American (Jan. 1984). 